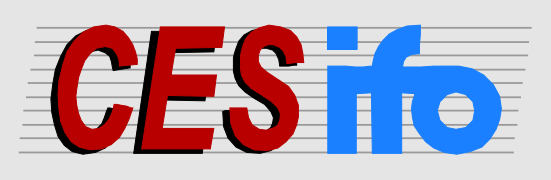

\title{
Working
}

Papers

www.cesifo.org/wp

\section{Minority Positions in the German Council of Economic Experts: A Political Economic Analysis}

\author{
Niklas Potrafke
}

\section{CESIFO WORKING PAPER NO. 4206 \\ CATEgory 2: Public CHOICE \\ APRIL 2013}
An electronic version of the paper may be downloaded
- from the SSRN website: Www.SSRN.com
- from the RePEc website: Www.RePEc.org
- from the CESifo website: www.CESifo-group.org/wp

\section{CESifo}




\title{
Minority Positions in the German Council of Economic Experts: A Political Economic Analysis
}

\begin{abstract}
I investigate minority votes in the German Council of Economic Experts. The dataset contains information on the voting behavior of the council members over the period 1971-2011. The results show that the best predictor of minority voting is being nominated by the trade unions: a council member nominated by the trade unions is about 70 percentage points more likely to vote against the majority opinion of the German Council of Economic Experts. This voting pattern indicates that the channel of political appointment influences voting behavior.
\end{abstract}

JEL-Code: D720.

Keywords: decision making in committees, minority voting, policy preferences, German Council of Economic Experts.

\author{
Niklas Potrafke \\ Ifo Institute - Leibniz-Institute \\ for Economic Research \\ at the University of Munich \\ Poschingerstraße 5 \\ Germany - 81679 Munich \\ potrafke@ifo.de
}

17 April 2013

This paper is forthcoming in the European Journal of Political Economy.

I would like to thank Christian Bjørnskov, Charles Blankart, Juergen Donges, Peter Egger, Lars Feld, Amihai Glazer, Carsten Hefeker, Arye Hillman, Richard Jong-A-Pin, Gebhard Kirchgässner, Michael Neugart, Volker Nitsch, Hannes Öhler, Klaus-Werner Schatz, Joachim Scheide, Volker Schmitt, Heinrich Ursprung, Roland Vaubel, and Amelie Wuppermann for their very helpful comments, hints, and suggestions. I am also grateful to Gavin Goy, Danny Kurban, Daniel Mannfeld, Margret Schneider and Felix Weber for their excellent research assistance and Lisa Giani Contini for proofreading the paper. 


\section{Introduction}

Political economists study voting in committees. ${ }^{2}$ A prominent example is voting in monetary policy committees (MPCs). ${ }^{3}$ Voting disagreements in MPCs usually relate to disagreements on how to design monetary policy such as interest rate proposals. Scholars examine why MPC members disagree and whether preference heterogeneity influences monetary policy. Determinants of dissent voting include members' internal and external status, career background, and the political channel of their appointment.

Studies on Federal Open Market Committee (FOMC) decision-making show that career background and the political channel of appointment influenced the voting behavior of the council members (e.g. Havrilesky and Schweitzer 1990, Chappell et al. 1993, Chappell et al. 2005). Democrat appointees exhibited very different voting behavior to Republican appointees (Chappell et al. 1993). Members of the German Bundesbank, too, seem to have voted for monetary policies favoring the parties which had nominated them in the pre-election period (Vaubel 1993, 1997a, 1997b, Berger and Woitek 1997). ${ }^{4}$ Using data for eleven European countries, Göhlmann and Vaubel (2007) show that the career background of central bank council members has influenced their inflation targets: former union leaders and politicians are the most inflation-prone group. ${ }^{5}$

\footnotetext{
${ }^{2}$ Gerling et al. (2005) survey theoretical studies on decision-making in committees. Game theorists investigate minority voting in committees (e.g. Fahrenberger and Gersbach 2010). See Seidmann (2011) on voting patterns and performance in private and public committees.

${ }^{3}$ See Berk and Bierut (2011) on communication in a monetary policy committee and Blinder (2007) on decisionmaking in a monetary policy committee. Riboni and Ruge-Murcia (2010) examine four different voting protocols in MCP policy-making. Belke and von Schnurbein (2012) examine the voting power of individual members of the ECB Governing Council. Berger et al. (2008) investigate the determinants of monetary policy committee size. Berger and Nitsch (2011) investigate how the size of monetary policy committees influences monetary policy.

${ }^{4}$ The results by Berger and Neugart (2011) show that the political leaning of German state governments influenced the appointment of judges in labor courts.

${ }^{5}$ By contrast, career background and the political channel of appointment hardly influenced the voting behavior of the council members of the Bank of England (Harris et al. 2011). The results obtained by Besley et al. (2008) show that there is preference for heterogeneity among MPC members at the Bank of England. However, members are not differentiated "according to their internal/external status, academic background, or experience in the Treasury" (p. 223). For a detailed account of preference heterogeneity between MPC members in Hungary and Poland and the FOMC, the Bank of England and Swedish Riksbank see also Jung and Kiss (2012) and Jung (2011). See Blinder et al. (2008) and Allard et al. (2013) on central bank communication.
} 
I investigate voting in another type of committee: the German Council of Economic Experts. Members of the Council, who are generally professors of economics, offer policy advice to the German government. These economists may disagree on the correct policies for different professional reasons, such as the effectiveness of monetary policy, the desired size of fiscal deficits, the balance between tax financing and government borrowing, the value of labor-supply elasticities etc. Differences may also be systematic and ideological, relating to the responsibilities of government and the weight placed on the income distribution consequences of policies relative to efficiency (see the summary in Hillman, 2009, chapter 10 on how the views held by economists can differ). The opinions on economic policy-making used to correlate with policy preferences (Alston et al. 1992, Fuchs et al. 1998, Mayer 2001, Klein and Stern 2006, Gordon and Dahl 2013). ${ }^{6}$ As compared to MPC committees, the members of the German Council of Economic Experts all have the same professional background. Differences in voting behavior in the German Council of Economic Experts may thus be more aligned with political ideology than professional background.

In this paper I study the voting patterns of members of the German Council of Economic Experts with a view to determining why views on policy differ. There are two competing hypotheses: either the coalitions on different votes are non-systematic in terms of membership, indicating differences in professional opinion based on idiosyncratic aspects of the proposed policies; or the coalitions are systematic and ideologically-based. If voting reveals that the coalitions are systematic and ideologically-based, voting could be regarded as expressive and as a means of confirming identity.

I investigate the relation between the source of nomination of Council members and whether members vote with the majority and minority. I find that members nominated by the

\footnotetext{
${ }^{6}$ Advising politicians appears to be influential in getting ideology-induced views implemented in real policymaking. Of course, economists may also have other motivations when advising politicians. Policy advice, for example, may be purely instrumental and benevolent; in other words given purely with a view to solving problems. Economists advising politicians and entrepreneurs are also likely to maximize their own utility by providing results that favour their clients (Kirchgässner 1996, 1999, 2005, 2011 and 2012).
} 
trade unions tend to vote with the minority. The members of the Council taking minority positions know that the majority position will influence actual policy and can propose their dissenting policy to confirm their identity as supportive of the ideology of those constituencies that nominated and supported them for Council membership.

\section{Data and descriptive analysis}

\subsection{The German Council of Economic Experts}

The German Council of Economic Experts has advised the Federal Government on matters of economic policy since $1964 .^{7}$ The Council assesses the current macroeconomic situation and forecasts future economic developments. ${ }^{8}$ The members of the Council enjoy independence in advising the government. On its webpage the Council claims that its advisory activities are an “essential part of German economic policy-making and have notably influenced political decisions” (German Council of Economic Experts, 2011).

The German Council of Economic Experts consists of five economics professors who have different fields of expertise. ${ }^{9}$ The formal procedure for becoming a member of the German Council of Economic Experts is as follows: the German federal government nominates candidates and the federal president appoints them. The informal procedure, however, is different. In fact, three members are nominated on the strength of their academic record. One member is nominated in consultation with the trade unions (union ticket) and one member is nominated in consultation with the employers' association (employers' ticket). It is important to note that the trade union and the employers' association do not directly nominate candidates. In the following I will use the terms "nominated by the trade unions" and “nominated by the employers' association" as simplification for "nominated in consultation

\footnotetext{
${ }^{7}$ Act on the Appointment of a Council of Experts on Economic Development. Dated August 14, 1963 (Federal Law Gazette I, page 685).

${ }^{8}$ See e.g. Rülke (2012).

${ }^{9}$ The government originally intended to have three economics professors and two practitioners in the Council: one practitioner nominated by the trade unions, and one practitioner nominated by the employers' association. I am grateful to Juergen Donges for this hint.
} 
with the trade unions" and "nominated in consultation with the employers' association". Previous members nominated by the trade unions include: Harald Koch (1964-1969), Claus Köhler (1969-1974), Gerhard Scherhorn (1974-1979), Werner Glastetter (1979-1982), HansJürgen Krupp (1982-1984), Dieter Mertens (1984-1986), Rüdiger Pohl (1986-1994), Wolfgang Franz (1994-1999), Jürgen Kromphardt (1999-2004), and Peter Bofinger (2004present). Members nominated by the employers’ association have been: Paul Binder (19641968), Manfred Schäfers (1968-1970), Armin Gutowski (1970-1978), Horst Albach (1978-

1983), Ernst Helmstädter (1983-1988), Ottmar Issing (1988-1990), Horst Siebert (19912003), and Wolfgang Franz (2003-2013).

The council members are generally appointed for a period of five years. Reappointment is possible. They elect one chairman for three years. Over the period 19632011, the German Council of Economic Experts has had 37 members. The average member served for 8.5 years.

\subsection{Minority votes in the German Council of Economic Experts}

In 1971, Claus Köhler submitted the first minority vote in the German Council of Economic Experts. Over the period 1971-2011, there have been 83 minority votes. I have compiled the minority votes by investigating all the reports issued by the German Council of Economic Experts over the period 1971-2011. The detailed list of all minority votes is available upon request.

Peter Bofinger and Hans-Jürgen Krupp, who were both nominated by the trade unions, are the record holders of minority votes in absolute terms. Peter Bofinger submitted 17 minority votes over the period 2004-2011. Hans-Jürgen Krupp submitted 17 minority votes on only three reports of the council (in 1982 and 1983). A total of 66 of the 83 minority votes were submitted by council members with the trade union ticket. By contrast, 11 of the 83 minority votes were submitted by council members with the employers' association ticket 
(Ernst Helmstädter 1, Wolfgang Franz 1 and Horst Siebert 9). 6 of the 83 minority votes were submitted by council members without a trade union or an employers' association ticket (Bert Rürup 5 and Beatrice Weder di Mauro 1). Table 1 lists the individual council members since 1964, shows the period they have served and the number of minority votes that they cast. Council members can submit minority votes on several individual issues of the final report of the German Council of Economic Experts. These descriptive statistics show that being nominated by the trade unions has a strong positive influence on submitting a minority vote.

Examples of dissent include labor market policies and fiscal policies: council members nominated by the trade unions do not balk at introducing comprehensive minimum wages and prefer a larger government. 
Table 1. List of council members and number of minority votes.

\begin{tabular}{|c|c|c|}
\hline Name & Member/Chairman & $\begin{array}{l}\text { \# minority } \\
\text { votes }\end{array}$ \\
\hline Bauer, Wilhelm & January 1964 - July 1974 & 0 \\
\hline Chairman & March 1964 - February 1970 & \\
\hline Binder, Paul & January 1964 - February 1968 & 0 \\
\hline Giersch, Herbert & January 1964 - February 1970 & 0 \\
\hline Koch, Harald & January 1964 - May 1969 & 0 \\
\hline Meyer, Fritz W. & January 1964 - February 1966 & 0 \\
\hline Stützel, Wolfgang & February 1966 - September 1968 & 0 \\
\hline Schäfer, Manfred & March 1968 - July 1970 & 0 \\
\hline Kloten, Norbert & June 1969 - April 1976 & 0 \\
\hline Chairman & March 1970 - February 1976 & \\
\hline Köhler, Claus & December 1969 - February 1974 & 6 \\
\hline Sievert, Olaf & May 1970 - February 1985 & 0 \\
\hline Chairman & March 1976 - February 1985 & \\
\hline Gutowski, Armin & December 1970 - February 1978 & 0 \\
\hline Scherhorn, Gerhard & May 1974 - February 1979 & 2 \\
\hline Schmidt, Kurt & August 1974 - May 1984 & 0 \\
\hline Fels, Gerhard & June 1976 - February 1982 & 0 \\
\hline Albach, Horst & May 1978 - February 1983 & 0 \\
\hline Glastetter, Werner & August 1979 - August 1981 & 2 \\
\hline Krupp, Hans-Jürgen & March 1982 - February 1984 & 17 \\
\hline Schneider, Hans K. & July 1982 - February 1992 & 0 \\
\hline Chairman & March 1985 - February 1992 & \\
\hline Helmstädter, Ernst & March 1983 - February 1988 & 1 \\
\hline Mertens, Dieter & March 1984 - February 1986 & 6 \\
\hline
\end{tabular}

Source: German Council of Economic Experts; own collection of the minority votes. 
Table 1. List of council members and number of minority votes (continued).

\begin{tabular}{|c|c|c|}
\hline Name & Member/Chairman & $\begin{array}{c}\text { minority } \\
\text { votes }\end{array}$ \\
\hline Pohmer, Dieter & July 1984 - February 1991 & 0 \\
\hline Hesse, Helmut & March 1985 - November 1988 & 0 \\
\hline Pohl, Rüdiger & July 1986 - February 1994 & 6 \\
\hline Issing, Otmar & April 1988 - September 1990 & 0 \\
\hline Hax, Herbert & March 1989 - February 2000 & 0 \\
\hline Chairman & March 1992 - February 2000 & \\
\hline Siebert, Horst & January 1991 - February 2003 & 9 \\
\hline Peffekoven, Rolf & April 1991 - February 2001 & 0 \\
\hline Donges, Juergen B. & April 1992 - February 2002 & 0 \\
\hline Chairman & March 2000 - February 2002 & \\
\hline \multirow[t]{2}{*}{ Franz, Wolfgang } & May 1994 - February 1999 & 1 \\
\hline & March 2003 - February 2013 & 1 \\
\hline Chairman & March 2009 - February 2013 & \\
\hline Kromphardt, Jürgen & March 1999 - February 2004 & 9 \\
\hline Rürup, Bert & March 2000 - February 2009 & 5 \\
\hline Chairman & March 2005 - February 2009 & \\
\hline Wiegard, Wolfgang & March 2001 - February 2011 & 0 \\
\hline Chairman & March 2002 - February 2005 & \\
\hline Weber, Axel A. & March 2002 - April 2004 & 0 \\
\hline Bofinger, Peter & March 2004 - & 17 \\
\hline $\begin{array}{l}\text { Weder di Mauro, } \\
\text { Beatrice }\end{array}$ & August 2004 - February 2012 & 1 \\
\hline Schmidt, Christoph M. & March 2009 - & 0 \\
\hline Feld, Lars P. & March 2011 - & 0 \\
\hline
\end{tabular}

Source: German Council of Economic Experts; own collection of the minority votes. 


\section{Econometric model}

I specify a probit model of the following form:

$$
\begin{aligned}
& {\text { Minority } \text { vote }_{i t}=\alpha+\beta \text { Union Ticket }}_{i t}+\gamma \text { Employers Ticket }_{i t} \\
& +\Sigma_{j} \delta_{j} \text { micro }_{i j t}+\varepsilon \text { Minority Position }_{i t}+\Sigma_{k} \zeta_{k} \text { macro }_{i k t}+u_{i t}
\end{aligned}
$$

$$
\text { with } i=1, \ldots, 31 ; j=1,2 ; k=1, \ldots, 6
$$

where Minority vote $_{i t}$ describes the voting behavior of council member $\mathrm{i}$ in year $\mathrm{t}$ and assumes the value one when council member i submitted a minority vote in year $\mathrm{t}$ and zero otherwise. Union Ticket $_{i t}$ describes a dummy variable that assumes the value one when council member i was nominated by the trade unions. Employers Ticket ${ }_{i t}$ describes a dummy variable that assumes the value one when council member i was nominated by the employers' association. $\Sigma_{j} \delta_{j}$ micro $_{i j t}$ describes other personal characteristic variables of council member i. I include the age of the council members and a dummy variable that assumes the value one when council member $\mathrm{i}$ is a macroeconomist. I focus on macroeconomics because the most pertinent ideological divides arise in this field. (I included other fields of expertise variables such as public finance, business administration and labor economics, but only a few council members have been experts in public finance, business administration and labor economics. Consequently, these dummy variables are dropped). The voting behavior of an individual council member may well depend on who the other council members are. If, for example, a majority of the three members who have not been nominated by the trade unions or the employers' association more or less share the views of the union representative, the union representative may be less likely to produce a dissenting opinion. Coding a minority/majority position of individual council members is difficult. I asked experts to identify council members who have been in a minority position. Based on this information I include a minority position dummy variable which assumes the value one when a council member was 
in a minority position. Because this minority position dummy variable is strongly correlated with the union ticket variable (the correlation coefficient is 0.66$),{ }^{10}$ I show results including and excluding the minority position dummy variable. $\Sigma_{k} \zeta_{k}$ macro $_{i k t}$ is a set of macroeconomic variables. I include the unemployment rate, the growth rate of real GDP, a dummy variable for a left-wing federal government that assumes the value one for left-wing governments, the value 0.5 when left-wing and right-wing parties formed a coalition government ("Grosse Koalition”) and zero for right-wing governments, and decadal dummy variables to consider external shocks (reference category is the time period after the year 2000). ${ }^{11}$ Table 2 shows descriptive statistics of all variables included.

I estimate a probit model with robust standard errors. The sample includes 203 observations: there is one observation per year in which an individual was a member of the council and voted on the report over the period 1971-2011. ${ }^{12}$

\footnotetext{
${ }^{10}$ The minority position variable assumes the value one for Claus Köhler, Gerhard Scherhorn, Werner Glastetter, Hans-Jürgen Krupp, Dieter Mertens, Helmut Hesse, Rüdiger Pohl, Wolfgang Franz (1994-1999), Jürgen Kromphardt, Bert Rürup (before 2003), Peter Bofinger (since 2009), Beatrice Weder di Mauro (since 2009), Wolfgang Wiegard (2004-2008), Wolfgang Franz (2004-2008). An alternative minority position coding does not consider Helmut Hesse to be in the minority. Inferences do not change using this alternative minority position coding. One expert suggested that only the Council members nominated by the trade unions have always been in a minority position. Elaborating on this view means that the union ticket and the minority position variable are identical. I have also used the nomination by a left-wing/right-wing government to identify whether an individual council member was in a minority. However, many of the members remained on the council for a number of years, even in cases where the government changed meaning that the new government did not replace potentially ideology-induced council members. Being nominated by a left-wing or right-wing government therefore does not appear to correctly label an individual member as being left-wing or right-wing.

${ }^{11}$ I consider the periods 1971-1980, 1981-1990, 1991-2000, and 2001-2011.

${ }^{12} \mathrm{I}$ do not include Dieter Mertens in 1985 because he was sick when the council members voted on the report.
} 
Table 2: Descriptive Statistics

\begin{tabular}{lcccccc}
\hline Variable & Observations & Mean & Std. Dev. & Min & Max & Source \\
\hline Minority votes (dummy) & 203 & 0.19 & 0.39 & 0 & 1 & Own Collection \\
Minority votes (number) & 203 & 0.41 & 1.17 & 0 & 10 & Own Collection \\
& & & & & & \\
Union Ticket & 203 & 0.20 & 0.40 & 0 & 1 & Own Collection \\
Employers Ticket & 203 & 0.20 & 0.40 & 0 & 1 & Own Collection \\
Age & 203 & 54.12 & 8.42 & 37 & 71 & Own Collection \\
Macro Economist & 203 & 0.21 & 0.41 & 0 & 1 & Own Collection \\
Public Finance Economist & 203 & 0.10 & 0.31 & 0 & 1 & Own Collection \\
Labor Economist & 203 & 0.09 & 0.28 & 0 & 1 & Own Collection \\
Business Administration & 203 & 0.11 & 0.32 & 0 & 1 & Own Collection \\
Minority Position & 203 & 0.28 & 0.45 & 0 & 1 & Own Collection \\
Minority Position & 203 & 0.26 & 0.44 & 0 & 1 & Own Collection \\
(alternative) & 203 & 8.12 & 3.33 & 0.8 & 13 & Federal Statistical Office \\
Unemployment rate & 203 & 2.06 & 1.99 & -5.1 & 5.3 & Federal Statistical Office \\
real GDP growth & 203 & 2.91 & 1.91 & -0.12 & 7.13 & Federal Statistical Office \\
Inflation & 203 & 0.52 & 0.48 & 0 & 1 & Own Collection \\
Left-wing federal & 203 & 0.59 & 0.48 & 0 & 1 & Own Collection \\
government & 193 & 69.48 & 9.75 & 54.3 & 83.02 & Dreher (2006) and \\
Initial Nomination by a Left- & & & & & & Dreher et al. (2008) \\
wing federal government & & & & & &
\end{tabular}

\section{Results}

\subsection{Basic results}

Table 3 shows the regression results of the coefficient estimates. The dependent variable is coded such that minority votes take on the value one and voting with the majority of the council members takes on the value zero. Positive coefficients of the explanatory variables thus mean that the explanatory variable induces a positive influence on submitting a minority vote and vice versa. Column (1) shows the results without control variables. In column (2), I have included the age variable and the macro economist dummy variable as basic personal characteristic control variables. In column (3), I have also included the minority position variable. Column (4) and (5) present the results when the macroeconomic control variables are included (with and without the minority position variable). Column (6) and (7) present the results when also the decadal dummy variables are included (with and without the minority position variable). 
The age variable has a positive sign and is statistically significant at the $1 \%$ level in columns (2) and (3), at the 10\% level in column (4), at the 5\% level in column (5), and lacks statistical significance in columns (6) and (7). This effect indicates that older council members have proven somewhat more likely to submit minority votes in the past. The macroeconomist variable, the minority position variable, the unemployment rate and real GDP growth do not turn out to be statistically significant. The left-wing federal government variable is statistically significant at the $10 \%$ level in column (4) but lacks statistical significance in the other columns. The decadal dummy variable for the 1970s and 1990s is statistically significant at the $1 \%$ level, and the decadal dummy variable for the 1980 s is statistically significant at the $5 \%$ level. The coefficients of the three decadal variables have a negative sign and indicate that there were fewer minority votes in the 1970s, 1980s and 1990s compared to the years after 2000 .

The results in Table 3 show that being nominated by the trade unions has a positive influence on submitting a minority vote: the coefficient of the Union Ticket variable has a positive sign and is statistically significant at the $1 \%$ level in columns (1) to (7). The Employers Ticket variable also has a positive sign and is statistically significant at the $5 \%$ level in columns (1), (2) and (4), and at the 1\% level in columns (3), (5), (6) and (7). Based on the coefficient estimates, we can calculate the marginal effects of the independent variables on the probability of submitting a minority vote. Table 4 shows the change in probability of submitting a minority vote when an individual council member has been nominated by the trade unions or the employers' association (I evaluate the marginal effects at the mean of the covariates). The results in Table 4 indicate that for a council member nominated by the trade unions, the probability of submitting a minority vote increases by about 70 percentage points, and that for a council member nominated by the employers' association, the probability of submitting a minority increases by about 20 percentage points. The results thus show that the 
best predictor of minority voting in the German Council of Economic Experts is being nominated by the trade unions.

Table 3. Regression Results. Coefficient estimates.

Probit, robust standard errors.

Dependent variable: minority vote dummy.

\begin{tabular}{|c|c|c|c|c|c|c|c|}
\hline Variable & $(1)$ & $(2)$ & (3) & $(4)$ & (5) & (6) & $(7)$ \\
\hline Union Ticket & $\begin{array}{c}2.369 * * * \\
(7.80)\end{array}$ & $\begin{array}{c}2.534 * * * \\
(6.64)\end{array}$ & $\begin{array}{c}2.203^{* * *} \\
(4.42)\end{array}$ & $\begin{array}{c}2.585^{* * *} \\
(6.50)\end{array}$ & $\begin{array}{c}2.277 * * * \\
(4.41)\end{array}$ & $\begin{array}{c}3.128 * * * \\
(8.38)\end{array}$ & $\begin{array}{c}2.949 * * * \\
(6.13)\end{array}$ \\
\hline Employers Ticket & $\begin{array}{c}0.809 * * \\
(2.47)\end{array}$ & $\begin{array}{c}0.792 * * \\
(2.31)\end{array}$ & $\begin{array}{c}0.849 * * * \\
(2.61)\end{array}$ & $\begin{array}{c}0.811^{* *} \\
(2.37)\end{array}$ & $\begin{array}{c}0.863 * * * \\
(2.63)\end{array}$ & $\begin{array}{c}1.048 * * * \\
(2.88)\end{array}$ & $\begin{array}{c}1.067 * * * \\
(2.94)\end{array}$ \\
\hline Age & & $\begin{array}{c}0.0403^{* * *} \\
(2.65)\end{array}$ & $\begin{array}{c}0.0436 * * * \\
(2.85)\end{array}$ & $\begin{array}{c}0.0361 * \\
(1.94)\end{array}$ & $\begin{array}{c}0.0403^{* *} \\
(2.24)\end{array}$ & $\begin{array}{c}0.0155 \\
(0.79)\end{array}$ & $\begin{array}{c}0.0171 \\
(0.87)\end{array}$ \\
\hline Macro Economist & & $\begin{array}{l}0.355 \\
(1.16)\end{array}$ & $\begin{array}{l}0.437 \\
(1.37)\end{array}$ & $\begin{array}{l}0.431 \\
(1.49)\end{array}$ & $\begin{array}{l}0.506 \\
(1.61)\end{array}$ & $\begin{array}{c}-0.0471 \\
(-0.16)\end{array}$ & $\begin{array}{c}-0.0114 \\
(-0.04)\end{array}$ \\
\hline Minority Position & & & $\begin{array}{l}0.539 \\
(1.43)\end{array}$ & & $\begin{array}{l}0.494 \\
(1.33)\end{array}$ & & $\begin{array}{l}0.255 \\
(0.69)\end{array}$ \\
\hline Unemployment rate & & & & $\begin{array}{c}0.0471 \\
(1.17)\end{array}$ & $\begin{array}{c}0.0356 \\
(0.93)\end{array}$ & $\begin{array}{l}-0.131 \\
(-1.44)\end{array}$ & $\begin{array}{l}-0.138 \\
(-1.52)\end{array}$ \\
\hline real GDP growth & & & & $\begin{array}{c}-0.0313 \\
(-0.45)\end{array}$ & $\begin{array}{c}-0.0365 \\
(-0.50)\end{array}$ & $\begin{array}{c}0.00931 \\
(0.11)\end{array}$ & $\begin{array}{c}0.00419 \\
(0.05)\end{array}$ \\
\hline Left-wing federal government & & & & $\begin{array}{c}0.554^{*} \\
(1.73)\end{array}$ & $\begin{array}{l}0.525 \\
(1.62)\end{array}$ & $\begin{array}{l}0.609 \\
(1.58)\end{array}$ & $\begin{array}{l}0.611 \\
(1.59)\end{array}$ \\
\hline $1970 \mathrm{~s}$ & & & & & & $\begin{array}{c}-2.685^{* * *} \\
(-3.01)\end{array}$ & $\begin{array}{c}-2.665 * * * \\
(-2.91)\end{array}$ \\
\hline $1980 s$ & & & & & & $\begin{array}{c}-0.892^{* *} \\
(-2.11)\end{array}$ & $\begin{array}{c}-0.835^{* *} \\
(-2.00)\end{array}$ \\
\hline $1990 \mathrm{~s}$ & & & & & & $\begin{array}{c}-1.380 * * * \\
(-2.81)\end{array}$ & $\begin{array}{c}-1.325 * * * \\
(-2.78)\end{array}$ \\
\hline Constant & $\begin{array}{c}-1.845^{* * *} \\
(-8.37)\end{array}$ & $\begin{array}{c}-4.179 * * * \\
(-4.47)\end{array}$ & $\begin{array}{c}-4.522 * * * \\
(-5.09)\end{array}$ & $\begin{array}{c}-4.603 * * * \\
(-4.04)\end{array}$ & $\begin{array}{c}-4.866 * * * \\
(-4.38)\end{array}$ & $\begin{array}{l}-1.228 \\
(-0.82)\end{array}$ & $\begin{array}{l}-1.351 \\
(-0.90)\end{array}$ \\
\hline Observations & 203 & 203 & 203 & 203 & 203 & 203 & 203 \\
\hline Pseudo R-squared & 0.397 & 0.425 & 0.437 & 0.447 & 0.456 & 0.524 & 0.526 \\
\hline
\end{tabular}

Table 4: Marginal Effects. Union Ticket and Employers Ticket on minority votes. Referring to Table 3.

\begin{tabular}{cccccccc}
\hline & $(1)$ & $(2)$ & $(3)$ & $(4)$ & $(5)$ & $(6)$ & $(7)$ \\
\hline Union Ticket & $0.707^{* * *}$ & $0.740^{* * *}$ & $0.633^{* * *}$ & $0.749^{* * *}$ & $0.651^{* * *}$ & $0.823^{* * *}$ & $0.778^{* * *}$ \\
& $(9.61)$ & $(8.79)$ & $(4.44)$ & $(8.81)$ & $(4.53)$ & $(13.46)$ & $(7.50)$ \\
\hline Employers Ticket & $0.200^{* *}$ & $0.187^{* *}$ & $0.193^{* *}$ & $0.188^{* *}$ & $0.194^{* *}$ & $0.207^{* *}$ & $0.206^{* *}$ \\
& $(2.16)$ & $(2.04)$ & $(2.13)$ & $(2.04)$ & $(2.10)$ & $(2.03)$ & $(1.98)$ \\
\hline
\end{tabular}




\subsection{Robustness Tests}

I have checked the robustness of the results in several ways. I have replaced the binary dependent variable with a dependent variable that considers the number of minority votes. Because the dependent variable includes an excessive number of zeros, I have estimated a zero-inflated negative binomial regression model with robust standard errors. The zeroinflated model distinguishes two processes: an individual council member submits minority votes or not (modeled by a logit model), and if s/he submits minority votes, the model considers the number of minority votes (modeled by a negative binomial model). The zeroinflated negative binomial models show that in cases where a council member has been nominated by the trade unions and submitted minority votes, the predicted number of additional minority votes per year is positive, but tiny. In cases where a council member has been nominated by the employers' association and submitted minority votes, the predicted number of additional minority votes per year does not turn out to be statistically significant.

I have tested whether voting behavior depends on whether a council member has initially been nominated by a left-wing or right-wing federal government and have therefore included a variable that assumes the value one for a left-wing government, the value 0.5 when left-wing and right-wing parties formed a coalition government (“Grosse Koalition”) and zero when the council member has initially been nominated by a right-wing government. ${ }^{13}$ The coefficient of this variable has a positive sign, but lacks statistical significance. Including this

\footnotetext{
${ }^{13}$ My coding refers to the government that was in power when an individual council member joined the Council. In cases where an individual council member joined the council some months after a change in government occurred, one may well want to employ an alternative coding that takes into account the party alignment of the government that initially nominated a council member. There are four cases to be considered. Claus Köhler joined the Council in December 1969 and Olaf Sievert in May 1970, while the government changed in October 1969. Ernst Helmstädter joined the Council in March 1983, following a government change in October 1982; and Jürgen Kromphardt joined the Council in March 1999, following a government change in October 1998. I cannot exactly retrace whether the previous government in the four cases already supported the nomination of the individual members. In any event, in cases where the new government did not support a nomination by a previous government, the new government was at liberty to nominate a new candidate. Moreover, Claus Köhler and Jürgen Kromphardt were nominated by the trade unions and Ernst Helmstädter was nominated by the employer's association.
} 
variable does not change the inferences regarding the Union Ticket and Employers Ticket variables at all.

The reported effects could be driven or mitigated by the idiosyncratic circumstances of individual council members. For this reason, I have tested whether the results are sensitive to the inclusion/exclusion of individual council members. Inferences do not change when excluding an individual council member.

A caveat applying to my econometric model concerns the potential reverse causality of the explanatory variables. In my analysis, however, reverse causality is not likely to be a serious problem. The trade unions and the employers' association nominate their candidates before the candidates have a chance to submit minority votes. I acknowledge that trade unions may, for example, appreciate minority voting against a market-oriented policy recommendation and therefore nominate a council member for a second period in office because this council member has submitted many minority votes in her/his first period in office. However, all council members with a trade union ticket except Rüdiger Pohl and Peter Bofinger served for only one term.

I have replaced the decadal dummy variables with a linear time trend. The economics profession has undergone a substantial change since the 1970 s as regards methods, particularly with respect to macroeconomics. The coefficient of the time trend variable has a positive sign and is statistically significant at the $10 \%$ and $5 \%$ level. Including the time trend does not change the inferences regarding the Union Ticket and Employers Ticket variable. In a similar vein, economists' views might have changed in the course of globalization. I have therefore included the KOF index of globalization for Germany to measure changes over time (Dreher 2006 and Dreher et al. 2008). The index is available for the period 1970-2009. The 
KOF index does not turn out to be statistically significant and including it does not change the inferences regarding the Union Ticket and Employers Ticket variable. ${ }^{14}$

\section{Conclusion}

The best predictor of minority voting in the German Council of Economic Experts is that a member of the Council was nominated for membership by the trade unions. A council member nominated by the trade unions is about 70 percentage points more likely to vote against the majority opinion. My results showing that council members nominated by the trade unions submit minority votes correspond with the empirical findings on voting in MPCs. In the FOMC and the German Bundesbank, the channel of political appointment has been shown to influence voting behavior: appointees nominated by the political left have voted differently from appointees nominated by the political right.

Dissent from the majority in the German Council of Economic Experts certainly confirms the dissenting expert's identity. Confirming identity is an element of expressive voting. ${ }^{15}$ A key question is the extent to which minority voting in the German Council of Economic Experts is purely expressive in the sense that it is motivated solely by the act of dissenting and not by the consequence of this act. ${ }^{16}$ Hillman (2010) proposes that expressive voting is a category of low-cost acts that enable individuals to confirm their identity to themselves and to others. Confirming identity to others is best achieved when voting is visible rather than anonymous. Hillman (2010) also proposes that expressive voting can result in an expressive policy trap whereby a majority of voters has voted for a policy that each voter

\footnotetext{
${ }^{14}$ I have also included the inflation rate that does not turn out to be statistically significant and including it does not change the inferences regarding the Union Ticket and Employers Ticket variable.

${ }^{15}$ A proposed solution to the paradox of voting (Downs 1957) is that voting is expressive (Buchanan 1954, Tullock 1971, Ursprung 1980, Brennan and Lomasky 1993, Brennan and Hamlin 2000, Drinkwater and Jennings 2007, Glazer 2008, Hillman 2010, Hamlin and Jennings 2011, Jennings 2013). The expressive voting hypothesis has been set in two alternative motivations. Brennan and Lomasky (1993) and Brennan and Hamlin (2000), and other formulations, describe expressive voting using the analogy of expressing support for a sports team.

${ }^{16}$ Majority voting could also be expressive. Minority votes would reflect expressive behavior to a greater extent because minority votes are more visible. For example, the media report on minority voting in the German Council of Economic Experts, but they do not report about majority voting.
} 
would veto individually if s/he were able to do so. The expressive policy trap is implicit in Tullock's observation (Tullock 1971) that individuals may support outcomes with the hope that they will be in the minority.

Even though expressing minority positions in the German Council of Economic Experts is a suitable instrument for confirming the one's identity it is not so that the members of the minority only take their minority positions when they know that they will be in the minority and their policy advice will not influence policy. ${ }^{17}$ In general, the members of the Council base their policy advice on pro-market positions that emphasize the role of incentives in economic behavior. The members nominated by the trade unions have different policy preferences and express their views regardless of whether they are in the minority or not.

\footnotetext{
${ }^{17}$ There is no evidence that the German government implemented policies based on a minority position or that a minority position became a majority position in the German Council of Economic Experts. Minority votes in committees may however become decisive. The results by Gerlach-Kristen (2004) show that the voting record of the monetary policy committee in the United Kingdom helped to predict future monetary policy changes: "if a minority votes for a lower level of the repo rate than the rest of the committee, the MPC is more likely to loosen monetary policy at the next meeting than to raise rates” (p. 312).
} 


\section{References}

Allard, J., Catenaro, M., Vidal, J.-P., Wolswijk, G. (2013). Central bank communication on fiscal policy European Journal of Political Economy 30, 1-14.

Alston, R., Kearl, J.R., Vaughan, M. (1992). Is there a consensus among economists in the 1990s? American Economic Review: Papers and Proceedings 82, 203-209.

Belke, A., von Schnurbein, B. (2012). European monetary policy and the ECB rotation model - voting power of the core versus the periphery. Public Choice 151, 289-323.

Berger H., Neugart, M. (2011). Labor courts, nomination bias, and unemployment in Germany. European Journal of Political Economy 27, 659-673.

Berger, H., Nitsch, V. (2011). Too many cooks? Committees in monetary policy. Southern Economic Journal 78, 452-475.

Berger, H., Nitsch, V., Lybek, T. (2008). Central bank boards around the world: Why does membership size differ? European Journal of Political Economy 24, 817-832.

Berger H., Woitek, U. (1997). How opportunistic are German central bankers: evidence on the Vaubel hypothesis. European Journal of Political Economy 13, 807-821.

Berk, J.M, Bierut, B.K. (2011). Communication in a monetary policy committee. European Journal of Political Economy 27, 791-801.

Besley, T., Meads, N., Surico, P. (2008). Insiders versus outsiders in monetary policymaking. American Economic Review: Papers \& Proceedings 98, 218-223.

Blinder, A. (2007). Monetary policy by committee: Why and how? European Journal of Political Economy 23, 106-123.

Blinder, A., Ehrmann, M., Fratzscher, M., de Haan, J., Jansen, J.-D. (2008). Central bank communication and monetary policy: A survey of theory and evidence. Journal of Economic Literature 46, 910-945.

Brennan, G., Hamlin, A. (2000). Democratic devices and desires. Cambridge University Press, Cambridge U.K.

Brennan, G., Lomasky, L. (1993). Democracy and decision. Cambridge University Press, Cambridge U.K.

Buchanan, J.M. (1954). Individual choice in voting and the market. Journal of Political Economy 62, 334-343.

Chappell, H.W.Jr., Havrilesky, T.M., McGregor, R.R. (1993). Partisan monetary policies: Presidential influence through the power of appointment. Quarterly Journal of Economics 108, 185-218. 
Chappell, H.W.Jr., McGregor, R.R., Vermilyea, T. (2005). Committee decisions on monetary policy. MIT Press, Cambridge.

Downs, A. (1957). An economic theory of democracy. Harper and Row, New York.

Dreher, A. (2006). Does globalization affect growth? Evidence from a new index of globalization. Applied Economics 38, 1091-1110.

Dreher, A., Gaston N., Martens P. (2008). Measuring globalization - Gauging its consequences. Springer, Berlin.

Drinkwater, S., Jennings, C. (2007). Who are the expressive voters? Public Choice 132, 179-189.

Fahrenberger, T., Gersbach, H. (2010). Minority voting and long-term decisions. Games and Economic Behavior 69, 329-345.

Fuchs, V., Krueger, A.B., Poterba, J. (1998). Economists’ views about parameters, values and policies: Survey results in labor and public economics. Journal of Economic Literature 36, 1387-1425.

Gerlach-Kristen, P. (2004). Is the MPC's voting record informative about future UK monetary policy? Scandinavian Journal of Economics 106, 299-313.

Gerling, K., Grüner, H.P., Kiel, A., Schulte, E. (2005). Information acquisition and decision making in committees: A survey.

European Journal of Political Economy 21, 563-597.

German Council of Economic Experts (2011). http://www.sachverstaendigenrat-wirtschaft.de/14.html?\&L=1, accessed on 10 December 2011

Glazer, A. (2008). Voting to anger and to please others. Public Choice 134, 247-254.

Göhlmann, S., Vaubel, R. (2007). The educational and occupational background of central bankers and its effect on inflation: An empirical analysis. European Economic Review 51, 925-941.

Gordon, R., Dahl, G.B. (2013). Views among economists: Professional consensus or pointcounterpoint? NBER Working Paper 18728.

Hamlin, A., Jennings, C. (2011). Expressive political behaviour: Foundations, scope and implications. British Journal of Political Science 41, 645-670.

Harris, M.N., Levine, P., Spencer, C. (2011). A decade of dissent: explaining the dissent voting behavior of Bank of England MPC members. Public Choice 146, 413-442. 
Havrilesky, T.M., Schweitzer, R. (1990). A theory of FOMC dissent voting with evidence from time series. In T. Mayer (Ed.): The political economy of American monetary policy. Cambridge University Press, Cambridge. 197-210.

Hillman, A.L. (2009). Public finance and public policy. 2nd edtion. Cambridge University Press. Cambridge.

Hillman, A.L. (2010). Expressive behavior in economics and politics. European Journal of Political Economy 26, 403-418.

Jennings, C. (2013). Institutions and prosperity. European Journal of Political Economy 29, 252-258.

Jung, A. (2011). An international comparison of voting by committees. ECB Working Paper No. 1383, Frankfurt.

Jung, A., Kiss, G. (2012). Preference heterogeneity in the CEE inflation-targeting countries. European Journal of Political Economy 28, 445-460.

Kirchgässner, G. (1996). Ideologie und Information in der Politikberatung: Einige Bemerkungen und ein Fallbeispiel. Hamburger Jahrbuch für Wirtschafts- und Gesellschaftspolitik 41, 9-41.

Kirchgässner, G. (1999). On the political economy of economic policy advice. In: E. Mohr (ed.), The Transfer of Economic Knowledge. Celtenham: Edward Elgar, 13-31. Kirchgässner, G. (2005). On the political economcy of economic policy advice: With applications of environmental policy. In: Ch. Böhringer und A. Lange (ed.), Applied Research in Environmental Economics. Heidelberg/New York: Physica, 277-298.

Kirchgässner, G. (2011). Der Ökonom als Berater: Objektivität, Ideologie und Eigeninteresse. In: M. Held, G. Kubon-Gilke und S. Sturn (ed.), Ökonomik in der Krise, Jahrbuch normative und institutionelle Grundlagen der Ökonomik, Band 10. Marburg: Metropolis, 219-241.

Kirchgässner, G. (2012). Zur Rolle der Ökonometrie in der wissenschaftlichen Politikberatung. Thünen-Vorlesung des Vereins für Socialpolitik, Göttingen 10. September 2012. Überarbeitete schriftliche Fassun November 2012.

Klein, D.B., Stern, C. (2006). Economists’ policy views and voting.

Public Choice 126, 331-342.

Mayer, T. (2001). The role of ideology in disagreements among economists: A quantitative analysis. Journal of Economic Methodology 8, 253-273.

Riboni, A., Ruge-Murcia, F.J. (2010). Monetary policy by committee: Consensus, chairman dominance, or simple majority? Quarterly Journal of Economics 125, 363-416. 
Rülke, J.-C. (2012). Do private sector forecasters desire to deviate from the German Council of Economic Experts? Jahrbücher für Nationalökonomie und Statistik 234, 414-428.

Seidmann, D.J. (2011). A theory of voting patterns and performance in private and public committees. Social Choice and Welfare 36, 49-74.

Tullock, G. (1971). The charity of the uncharitable.

Western Economic Journal 9, 379-392.

Ursprung, H.W. (1980). Voting behavior in a system of concordant democracy. Public Choice 35, 349-362.

Vaubel, R. (1993). Eine Public-Choice-Analyse der Deutschen Bundesbank und ihre Implikationen für die Europäische Währungsunion, in Duwendag D. and Siebke J. (Eds), Europa vor dem Eintritt in die Wirtschafts- und Währungsunion, Duncker und Humblot, Berlin, 23-79.

Vaubel, R. (1997a). The bureaucratic and partisan behaviour of independent central banks: German and international evidence, European Journal of Political Economy 13, 201-224.

Vaubel R. (1997b). Reply to Berger and Woitek, European Journal of Political Economy 13, 823-827. 